\title{
Left ventricular platelet deposition after acute myocardial infarction \\ An attempt at quantification using blood pool subtracted
indium-111 platelet scintigraphy
}

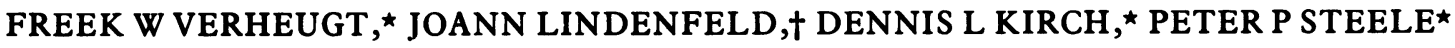 \\ From the ${ }^{\star}$ Division of Cardiology, Department of Medicine, Veterans Administration Medical Center; and the \\ †Division of Cardiology, Department of Medicine, University of Colorado Health Sciences Center, Denver, Colorado, \\ USA
}

SUMMARY Since indium-111 platelet scintigraphy for the detection of left ventricular thrombosis often shows considerable non-specific blood pool activity a subtraction method using simultaneous technetium-99m blood pool scintigraphy was undertaken in 11 subjects with well documented remote myocardial infarction, who served as positive or negative controls, and in 18 consecutive patients with acute myocardial infarction. The results were compared with those of cross sectional echocardiography. Thirteen patients had transmural myocardial infarction and the calculated count per pixel in the left ventricle of the subtracted indium-111 platelet scintigram was (mean (SD)) $0.28(0.35)$, but five patients with subendocardial myocardial infarction had a mean count of 0.04(0.06). In seven patients with transmural myocardial infarction (two anterior and five inferior) left ventricular thrombosis was detected by indium-111 platelet scintigraphy but in only one of these by cross sectional echocardiography. None of the patients with subendocardial myocardial infarction had left ventricular thrombosis. Subtracted left ventricular counts correlated well with the visual results.

It is concluded that left ventricular platelet sequestration after acute myocardial infarction may be quantified and precisely located and that quantitative longitudinal studies of the natural history and drug intervention are now possible.

One of the complications of acute myocardial infarction is arterial embolism. The source is thought to be the left ventricle, where thrombi form on the infarcted endocardium. The introduction of cross sectional echocardiography and, recently, of indium-111 platelet scintigraphy has made the non-invasive diagnosis of left ventricular thrombi possible. ${ }^{1-4}$ Cross sectional echocardiography is, however, not possible in every patient and is often equivocal in defining endocardium-thrombus and thrombus-blood boundaries. ${ }^{56}$ With indium-111 platelet scintigraphy it is

Requests for reprints to Dr Freek W Verheugt, Department of Cardiology, Free University Hospital, De Boelelaan 1117, 1007 MB Amsterdam, The Netherlands.

Accepted for publication 13 July 1984 sometimes difficult to distinguish platelet deposition from platelets circulating in the blood pool.

Thus we developed a subtraction method using low dose technetium-99m blood pool imaging simultaneously with indium-111 platelet scintigraphy in an attempt to improve diagnostic accuracy and to make cardiac indium-111 platelet scans quantitative for intracardiac platelet deposition. This study was undertaken to compare the relative accuracy of cross sectional echocardiography and platelet scintigraphy in detecting left ventricular thrombosis after acute myocardial infarction.

Patients and methods

CONTROL GROUP

Eleven men (mean (SD) age 57(4) (range 52-63) 
Table 1 Characteristics and results in control group

\begin{tabular}{|c|c|c|c|c|c|c|c|}
\hline $\begin{array}{l}\text { Case } \\
\text { No }\end{array}$ & $\begin{array}{l}\text { Sex and } \\
\text { age }(y r)\end{array}$ & $\begin{array}{l}\text { Myocardial } \\
\text { infarction }\end{array}$ & Interoal & $\begin{array}{l}\text { Cross } \\
\text { sectional } \\
\text { echocardiography }\end{array}$ & $\begin{array}{l}L V \\
\text { cineangiography }\end{array}$ & $\begin{array}{l}\text { Indium } \\
\text { (visual) }\end{array}$ & $\begin{array}{l}\text { Indium } L V \\
(c p p-n s)^{\star}\end{array}$ \\
\hline $\begin{array}{c}1+ \\
2 \ddagger \\
3 \ddagger \\
4 \\
5 \\
6 \\
7 \\
8 \\
9 \\
10 \\
11 \ddagger\end{array}$ & 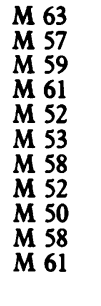 & $\begin{array}{l}\text { Anterior } \\
\text { Anterior } \\
\text { Anterior } \\
\text { Anterior } \\
\text { Anterior } \\
\text { Anterior } \\
\text { Inferior } \\
\text { Inferior } \\
\text { Inferior } \\
\text { Inferior } \\
\text { Subendo- } \\
\text { cardial }\end{array}$ & $\begin{array}{l}10 \text { mnth } \\
1 \text { yr } \\
3 \text { yr } \\
1 \text { yr } \\
7 \text { mnth } \\
7 \text { mnth } \\
9 \text { mnth } \\
6 \text { yr } \\
7 \text { yr } \\
11 \mathrm{yr} \\
11 \text { mnth }\end{array}$ & $\begin{array}{l}+ \\
\text { ND } \\
0 \\
0 \\
0 \\
+ \\
\text { ND } \\
0 \\
0 \\
0 \\
0\end{array}$ & $\begin{array}{l}0 \\
0 \\
0 \\
0 \\
+ \\
+ \\
0 \\
+ \\
0 \\
0 \\
0\end{array}$ & $\begin{array}{l}+ \text { (Anterior) } \\
0 \\
0 \\
0 \\
+ \text { (Anterior) } \\
+ \text { (Anterior) } \\
0 \\
+ \text { (Inferior) } \\
0 \\
0 \\
0\end{array}$ & $\begin{array}{l}0.13 \\
0.26 \\
0.00 \\
0.11 \\
0.59 \\
0.55 \\
0.09 \\
0.42 \\
0.08 \\
0.05 \\
0.18\end{array}$ \\
\hline
\end{tabular}

^LV cpp-ns, normalised left ventricular counts per pixel in subtracted image (see text).

$\dagger$, Took sulphinpyrazone $200 \mathrm{mg}$ four times daily.

$¥$, Took acetylsalicylic acid $325 \mathrm{mg}$ once daily.

+ , positive; 0 , negative; ND, not done.

years) having had a myocardial infarction more than three months before the study (median interval 12 months, range 7 months to 7 years) served as control subjects. The infarcts were diagnosed on the basis of a typical history, serial electrocardiograms, and typical enzyme patterns of creatine phosphokinase, creatine kinase $M B$, serum aspartate aminotransferase, and lactate dehydrogenase. They were admitted to hospital at the time of the study because of angina, congestive heart failure, or arrhythmia and underwent left heart catheterisation including left ventricular cineangiography. They were divided into two groups: those with evidence of left ventricular thrombus on cross sectional echocardiography or left ventricular cineangiography or both $(n=4)$ and those without $(n=7)$. Table 1 shows their clinical characteristics.

\section{STUDY GROUP}

The study population consisted of 18 consecutive patients (16 men, two women, age 52(12) (range 3069) years) who had had a first acute myocardial infarction less than two weeks before the study. The acute infarcts were diagnosed on the basis of a typical history, serial electrocardiograms, and typical enzyme patterns of creatine phosphokinase, creatine kinase $M B$, serum aspartate aminotransferase, and lactate dehydrogenase. Those patients who developed wide and deep $Q$ waves during the evolution of their infarct were considered to have a transmural myocardial infarct $(n=13)$. Those who did not and had otherwise the typical picture of an acute myocardial infarction including ST-T wave changes and enzyme changes were diagnosed as having a subendocardial infarct $(n=5)$. Table 2 shows the other characteristics of the patients. None of the patients had or had had symptomatic systemic emboli. All received $50 \mathrm{mg}$ heparin subcutaneously twice daily.

All patients participated in the study after written informed consent. Approval for this study was obtained from the human subject committee of the University of Colorado Health Sciences Center.

\section{INDIUM-111 PLATELET LABELLING AND INJECTION}

A volume of 200 to $300 \mathrm{ml}$ blood was drawn from patients in closed bags containing $67.5 \mathrm{ml}$ citrate dextrose solution and centrifuged at $250 \mathrm{~g}$ for $10 \mathrm{~min}$. Platelet rich plasma was collected and the packed red cells returned to the patients. Platelet rich plasma was centrifuged thereafter at $1750 \mathrm{~g}$ for $10 \mathrm{~min}$ and the platelets were resuspended in about $8 \mathrm{ml}$ citrate buffer.

Indium-111 chloride was complexed with oxine according to the method of Scheffel et al..$^{7}$ About 500 $\mu \mathrm{Ci}(18.5 \mathrm{MBq})$ of indium-111 oxine was incubated for $15 \mathrm{~min}$ at $37^{\circ} \mathrm{C}$ with the platelet suspension at a indium-111-oxine concentration of $6.25 \mu \mathrm{g} / \mathrm{ml}$. The indium-111 labelled platelets were washed twice in citrate buffer, centrifuged at $1750 \mathrm{~g}$ for $10 \mathrm{~min}$, and resuspended in $20 \mathrm{ml}$ citrate buffer. The suspension was transferred to a $20 \mathrm{ml}$ syringe and the radioactivity determined in a dosimeter. The labelling efficacy was then calculated and found to be $49(23) \%$. No more than $200 \mu \mathrm{Ci}(7.4 \mathrm{MBq})$ platelet bound indium was used for injection because of irradiation exposure to the patients. The suspension or a part of it was injected in the antecubital vein with an 18 gauge needle.

RADIONUCLIDE IMAGING AND BLOOD COUNTING Forty eight hours after the injection of indium-111 labelled platelets radionuclide imaging was performed using a large field gammacamera interfaced to a dedicated computer system. Imaging was done with a medium energy parallel hole collimator. Images were acquired in a $128 \times 128$ mode using 1.5 times 
Table 2 Characteristics and results in patients with acute myocardial infarction

\begin{tabular}{|c|c|c|c|c|c|c|}
\hline $\begin{array}{l}\text { Case } \\
\text { No }\end{array}$ & $\begin{array}{l}\text { Sex and } \\
\text { age (yr) }\end{array}$ & $\begin{array}{l}\text { Myocardial } \\
\text { infarction }\end{array}$ & $\begin{array}{l}\text { Cross } \\
\text { sectional } \\
\text { echocardiography }\end{array}$ & $\begin{array}{l}\text { Indium } \\
\text { dose } \\
(\mu C i)\end{array}$ & $\begin{array}{l}\text { Indium } \\
\text { (visual) }\end{array}$ & $\begin{array}{l}\text { Indium } \\
(L V c p p-n s)^{\star}\end{array}$ \\
\hline 1 & F 64 & Transmural, & 0 & 60 & + (Anterior) & 0.53 \\
\hline 2 & M 30 & $\begin{array}{c}\text { Transmural, } \\
\text { anterior }\end{array}$ & 0 & 199 & 0 & 0.00 \\
\hline 3 & M 69 & $\begin{array}{c}\text { Transmural, } \\
\text { anterior }\end{array}$ & 0 & 21 & 0 & 0.01 \\
\hline 4 & M 41 & $\begin{array}{c}\text { Transmural, } \\
\text { anterior }\end{array}$ & 0 & 36 & 0 & 0.00 \\
\hline 5 & M 47 & $\begin{array}{c}\text { Transmural, } \\
\text { anterior }\end{array}$ & + & 82 & + (Anterior) & 1.29 \\
\hline 6 & M 50 & $\begin{array}{c}\text { Transmural, } \\
\text { anterior }\end{array}$ & 0 & 54 & 0 & 0.16 \\
\hline 7 & M 30 & $\begin{array}{c}\text { Transmural, } \\
\text { inferior }\end{array}$ & 0 & 83 & 0 & 0.03 \\
\hline 8 & M 66 & $\begin{array}{c}\text { Transmural, } \\
\text { inferior }\end{array}$ & 0 & 120 & 0 & 0.00 \\
\hline 9 & M 56 & $\begin{array}{c}\text { Transmural, } \\
\text { inferior }\end{array}$ & 0 & 44 & $+($ Inferior $)$ & 0.34 \\
\hline 10 & F 62 & $\begin{array}{c}\text { Transmural, } \\
\text { inferior }\end{array}$ & 0 & 92 & $+\begin{array}{c}\text { (Inferior, } \\
\text { posterior) }\end{array}$ & 0.37 \\
\hline 11 & M 41 & $\begin{array}{c}\text { Transmural, } \\
\text { inferior }\end{array}$ & 0 & 200 & $+\begin{array}{c}\text { (Inferior, } \\
\text { posterior) }\end{array}$ & 0.39 \\
\hline 12 & M 66 & $\begin{array}{c}\text { Transmural, } \\
\text { inferior }\end{array}$ & 0 & 89 & + (Posterior) & 0.17 \\
\hline 13 & M 48 & $\begin{array}{c}\text { Transmural, } \\
\text { inferior }\end{array}$ & 0 & 81 & + (Inferior) & 0.33 \\
\hline $14 \dagger$ & M 46 & $\begin{array}{l}\text { Subendo- } \\
\text { cardial }\end{array}$ & 0 & 200 & 0 & 0.15 \\
\hline $15 t$ & M 64 & $\begin{array}{l}\text { Subendo- } \\
\text { cardial }\end{array}$ & 0 & 80 & $\mathbf{0}$ & 0.00 \\
\hline 16 & M 39 & $\begin{array}{l}\text { Subendo- } \\
\text { cardial }\end{array}$ & 0 & 152 & 0 & 0.00 \\
\hline 17 & M 50 & $\begin{array}{l}\text { Subendo- } \\
\text { cardial }\end{array}$ & 0 & 78 & 0 & 0.02 \\
\hline 18 & M 61 & $\begin{array}{l}\text { Subendo- } \\
\text { cardial }\end{array}$ & 0 & 136 & 0 & 0.03 \\
\hline
\end{tabular}

$\star$ LV cpp-ns, normalised left ventricular counts per pixel in subtracted image (see text).

†Took sulphinpyrazone $200 \mathrm{mg}$ four times daily.

0 , negative; +, positive. Conversion: traditional to SI units-indium: $1 \mu \mathrm{Ci} \approx 0.037 \mathrm{MBq}$.

magnification. For the indium image the camera was set up to use a $20 \%$ window for both the 172 and 248 $\mathrm{keV}$ peaks of indium-111. The amounts of indium injected required at least $30 \mathrm{~min}$ of imaging time to produce acceptable integral counts (150 000 counts). The image was acquired in the $45^{\circ}$ left anterior oblique projection. Before the indium imaging began 20 $\mathrm{ml}$ blood was drawn and $12 \mathrm{mg}$ unlabelled pyrophosphate was injected for subsequent in vivo red cell labelling.

After acquisition of the indium image $2-5 \mathrm{mCi}$ (100-200 MBq) technetium-99m pertechnetate was injected and the camera was set at a $20 \%$ energy window at the $140 \mathrm{keV}$ peak of technetium- $99 \mathrm{~m}$, the patient and the camera being kept in the same position as during the indium imaging. After $5 \mathrm{~min}$ equilibrium, ungated blood pool images were acquired using a $5 \mathrm{~min}$ imaging time and a final $20 \mathrm{ml}$ blood sample was taken.

Both the blood samples were placed in a shielded fixture attached to the collimator and counted with the same energy window and photo peak settings as used for imaging. With this method indium-111 to technetium- $99 \mathrm{~m}$ blood count ratios could be determined after correction for decay and imaging time and used for blood pool subtraction of the indium images.

Subtracted images were subject to calculation of platelet deposition. They were also photographed on Polaroids. These pictures were interpreted by two independent investigators and regarded as positive when localised indium uptake in the left ventricle (hot spot) was seen by both observers.

In the patients with acute myocardial infarction and a positive indium-111 scintigram an indium-111 image with the camera in the anterior position was acquired $24 \mathrm{~h}$ after the quantitative study to localise the indium uptake in the left ventricle.

\section{CALCULATION OF LEFT VENTRICULAR PLATELET DEPOSITION}

Both the indium and the technetium images were smoothed using a $3 \times 3$ equal weight filter. The smoothed images were added in order to create an overlay by drawing areas of interest in the region of 
With platelet deposition

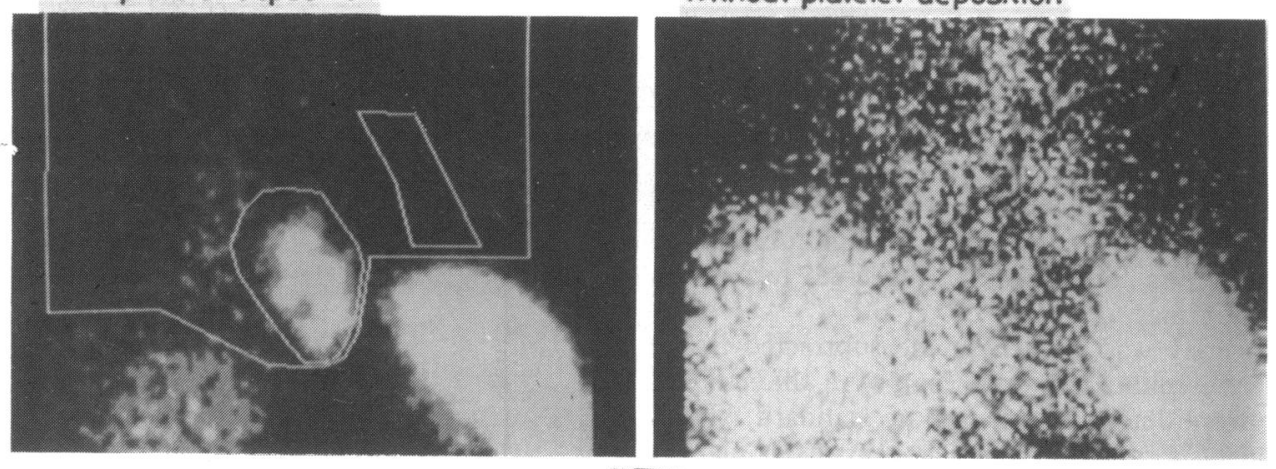

(a)
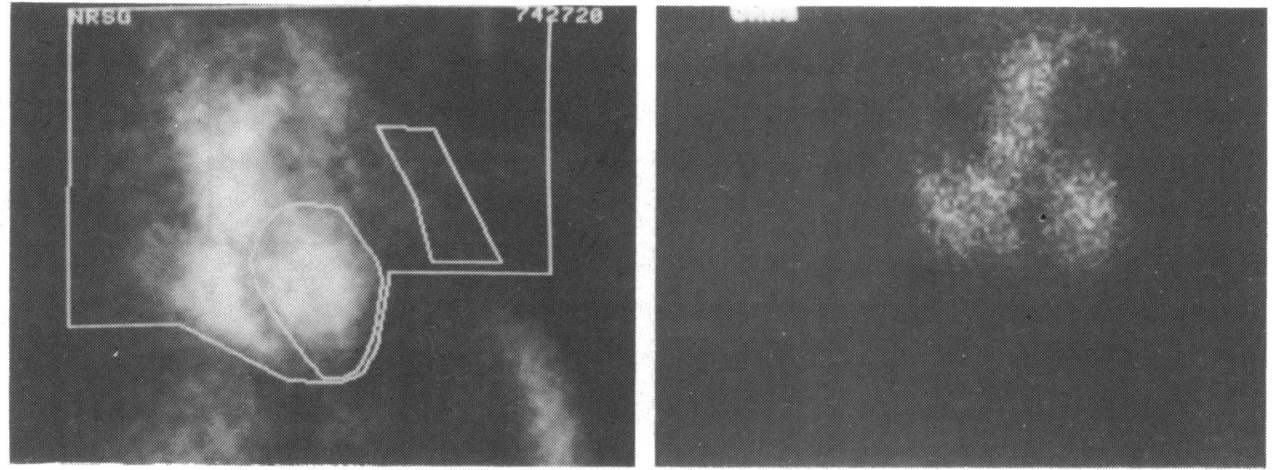

(b)
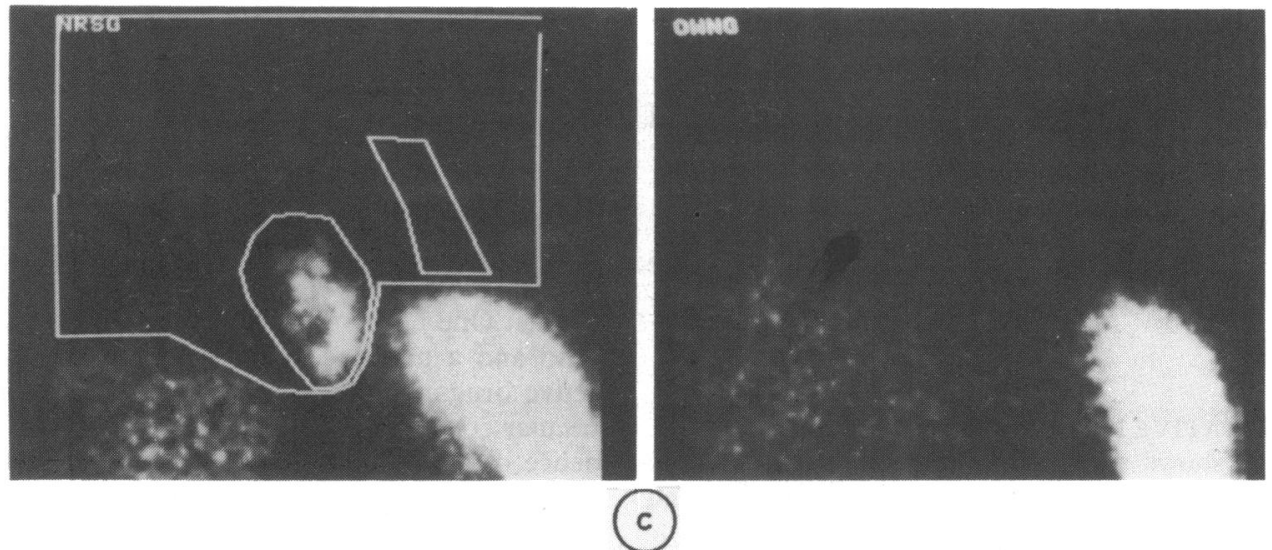

Fig. 1 Scintigrams of two patients with transmural anterior infarction, one with left ventricular thrombosis and one without platelet deposition: (a) indium images (left anterior oblique view) (note the accumulation of indium in the left ventricle but also blood pool imaging), (b) technetium blood pool images, and (c) subtracted indium images (note the intense indium deposition in the apical area and the absence of blood pool image.) Areas of interest are drawn around the left ventricle, a part of the left lung, and the thorax area. This overlay is used for landmarks in the calculation of left ventricular platelet deposition. 
the left ventricle, the surrounding lung tissue (background), and the thorax (Fig. 1). The images were added because the technetium left ventricular images might show filling defects caused by thrombi. ${ }^{8}$ Subsequently, the technetium image was subtracted from the indium image according to the formula: subtracted image $=$ indium image $-(\mathrm{K} \times$ technetium image), in which $\mathrm{K}$ represents the indium-111 to technetium-99m blood ratio corrected for image acquisition times.

The overlay was applied to the subtracted image (s), and the counts per pixel (cpp-s) in the areas of interest were determined using the standard ADAC image analysis software. The left ventricular platelet deposition was expressed as left ventricular counts per pixel normalised for the counts per pixel in the thoracic area in the subtracted image: $\mathrm{LV} \mathrm{cpp}-\mathrm{ns}=$ (LV cpp-s-background cpp-s)/thoracic cpp-s.

\section{ECHOCARDIOGRAPHY}

A phased array sector scanner was used for the cross sectional echocardiographic studies. Between the platelet labelling and radionuclide imaging the control patients underwent echocardiography. In two control patients high quality echocardiograms could not be obtained. The 18 patients with acute myocardial infarction underwent serial cross sectional echocardiography. In each of these patients at least two recordings were made with a minimum interval of $48 \mathrm{~h}$. Long axis, short axis, and apical or subxiphoid four chamber views were acquired on video tape and analysed by two independent interpreters. A thrombus was defined as a mass in the left ventricle which was visible on at least two views with a sharp border well in contact with the endocardium. Images that had equivocal or inconclusive results were considered to be negative.

\section{STATISTICAL ANALYSIS}

The techniques used for statistical analysis of results are mentioned each time they were used.

\section{Results}

QUANTITATIVE INDIUM-111 PLATELET IMAGING

Figure 1 shows several images of a patient with an acute transmural anterior myocardial infarction and left ventricular thrombosis and the same frames of one with anterior myocardial infarction without platelet deposition: $(a)$ the indium image $48 \mathrm{~h}$ after reinfusion of indium-111 labelled platelets, $(b)$ the technetium$99 \mathrm{~m}$ blood pool image, made within $10 \mathrm{~min}$ of $(a)$, and (c) the subtracted image showing intense localised platelet deposition in the anterolateral region.

Table 1 shows the results of the indium platelet imaging, cross sectional echocardiography, and left
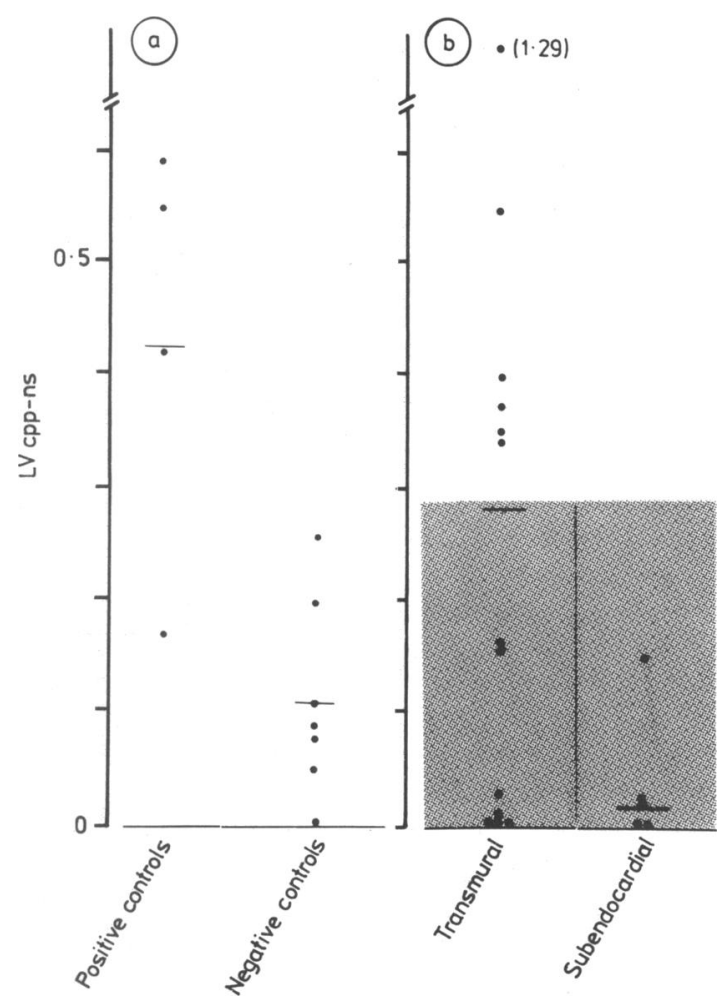

Fig. 2 Results of quantitative platelet scintigraphy in (a) the control patients and $(b)$ the patients with acute myocardial (transmural and subendocardial) infarction; shaded area represents mean (2SD) of the negative control values. Bars denote mean. LVCPp-ns, normalised left ventricular counts per pixel in subtracted image.

ventricular cineangiography in the control group. Four patients had positive echocardiograms or cineangiograms or both and served as positive controls. All four also had positive indium images and had (mean (SD) ) $0.42(0.21)$ subtracted left ventricular counts. One positive control (case 1) (with a positive echo and a negative angiogram and taking platelet active drugs) showed only 0.13 subtracted left ventricular counts. The other seven patients had no evidence of thrombi on any of the tests and served as negative controls. They had $0 \cdot 11(0.09)$ subtracted left ventricular counts. Figure 2a summarises results in the control patients.

Table 2 gives the results of the 18 patients with acute myocardial infarction. Six patients, two with anterior transmural infarction and four with inferior transmural infarction, had subtracted left ventricular counts higher than 0.29 -that is, the mean plus $2 \mathrm{SD}$ in the negative controls. All six had left ventricular indium deposition in their subtracted images, which 
Table 3 Comparison of cross sectional echocardiography and indium-111 scintigraphy in acute myocardial infarction $(n=18)$

\begin{tabular}{llc}
\hline $\begin{array}{lll}\text { Cross sectional } \\
\text { echocardiography }\end{array}$ & \multicolumn{2}{l}{ Indium-111 } \\
\cline { 2 - 3 } & scintigraphy \\
\hline Positive & Negative \\
\hline Pegitive & 1 & 0 \\
\hline
\end{tabular}

were considered to be positive. One patient (case 12) with a transmural inferior myocardial infarction had a positive indium image and only 0.17 subtracted left ventricular counts.

In all patients with a positive indium image the site of deposition correlated well with the electrocardiographic localisation of the infarct. The results of the indium images were not correlated with the concomitant use of platelet-active drugs (NS, $\chi^{2}$ test with Yates's correction) nor with the injected dose (mean, SD) of indium-111: 93(50) $\mu \mathrm{Ci}$ for the patients with a positive image and $105(61) \mu \mathrm{Ci}$ for those with a negative image (NS, unpaired $t$ test). Figure $2 \mathrm{~b}$ summarises the scintigraphic results of Table 2 . The patients with a transmural infarct had (mean, SD) $0.28(0.35)$ subtracted left ventricular counts and those with a subendocardial infarct $0.04(0.06)$ counts $(p<0.05$, Wilcoxon rank sum test).

\section{ECHOCARDIOGRAPHIC FINDINGS}

Table 3 gives the results of cross sectional echocardiography compared with those of indium-111 platelet scintigraphy in the patients with acute myocardial infarction. In acute myocardial infarction quantitative indium platelet scintigraphy showed left ventricular thrombosis more often than cross sectional echocardiography.

\section{Discussion}

In this prospective study the incidence of platelet deposition found with indium-111 scintigraphy in consecutive patients with acute infarction was $39 \%$, which is similar to previous observations ${ }^{9}$ and to necropsy results of similar patients. ${ }^{10}$ None of our patients had episodes of systemic embolism. The in vivo incidence of left ventricular thrombus in consecutive cases of acute myocardial infarction is from $2 \%{ }^{11}$ to $22 \%^{12}$ by cross sectional echocardiography, which is similar to our observations, and transmural anterior infarction seems especially likely to give rise to thrombi. The other method for detecting left ventricular thrombi, indium-111 platelet scintigraphy, is highly specific and sensitive in patients at high risk of developing left ventricular thrombi. ${ }^{2}$

Like echocardiography indium-111 platelet scintig- raphy can localise left ventricular thrombi. Using simultaneous technetium-99m blood pool scanning for subtraction purposes, landmarks may be made in the subtracted indium images. In the patients with acute myocardial infarction we found a strong correlation between the site of the specific platelet deposition and that of the infarct by electrocardiography.

Since conventional indium-111 platelet scintigrams of the cardiac area also show blood pool, the blood pool image may easily mask areas of platelet deposition in the left ventricle. Nevertheless, quantitative platelet scintigraphy was not found to be more sensitive than conventional platelet scintigraphy in this study, but it has the major advantage of quantification. In general, quantification of the left ventricular platelet deposition correlated well with the visual results. Some patients with an acute infarction, however, who had a negative scintigram (by both observers), had detectable indium uptake in their images. Since background correction is needed, also in the subtracted image, we used an area in the left lung region for that purpose. Indium uptake by the lung, probably by reticuloendothelial cells, must be subtracted from the cardiac image. We noticed pronounced interindividual differences in indium lung uptake. This may explain the discrepancy in the calculation of platelet deposition and the visual result, as may the difference in tissue attenuation of technetium and indium.

Pathological validation of low but detectable platelet deposition in the left ventricle could not be provided in this study, nor in other studies of the quantification of platelet deposition in coronary ${ }^{13}$ or peripheral artery $\mathrm{graft}^{14}$ thrombosis. Thus, the importance of very low indium counts in subtracted images is unclear. Therefore, quantification using blood pool subtraction or other techniques does not so far seem to improve the diagnositic accuracy of platelet scintigraphy.

In our study the incidence of definite left ventricular thrombus in acute infarction found by cross sectional echocardiography was low (6\%). One explanation might be that high quality echocardiography is not feasible in every patient. Echocardiograms may easily be misinterpreted, 615 especially in the evaluation of left ventricular masses. ${ }^{516}$ Secondly, the difference in echo density of blood and thrombus might be critical in early thrombosis. Furthermore, since the discrepancy between echo and platelet scintigraphy in this study was especially pronounced in the cases of acute transmural inferior myocardial infarction, cross sectional echocardiography may possibly miss inferoposterior wall masses more easily than anteroapicolateral space occupying lesions. Left ventricular thrombosis also occurs frequently in inferior myocardial infarction. Indirect evidence of this is 
given in a surgical study showing the equal incidence of peripheral embolism in anterior and inferior infarction. ${ }^{17}$

Furthermore, platelet scintigraphy and echocardiography may possibly show different intraventricular phenomena in acute infarction. Positive scintigrams do not necessarily mean the presence of a thrombus in the pathological sense but more likely the deposition of platelets on infarcted endocardium, which may not be visible on examination with the ultrasound beam. Whether platelet deposition alone is a risk for symptomatic systemic embolisation remains to be established.

In this study we could not confirm the statement, posed in previous echocardiography-scintigraphy studies, ${ }^{1819}$ that platelet scintigraphy detects only "hematologically active" thrombi since we found no echo-positive/scintigraphy-negative cases. We did not expect such a finding in patients with acute myocardial infarction.

This study is, to the best of our knowledge, the first to compare cross sectional echocardiography and platelet scintigraphy in the diagnosis of left ventricular thrombus in consecutive patients with acute myocardial infarction. The sensitivity of cross sectional echocardiography for identifying left ventricular thrombi in consecutive cases of acute myocardial infarction compared with indium-111 platelet scintigraphy should be studied further.

We found that indium-111 platelet scintigraphy is a valid test for detecting platelet sequestration in the left ventricle in acute myocardial infarction, as already observed by others. ${ }^{12}$ The clinical implications of left ventricular platelet deposition in acute infarction in relation to symptomatic arterial embolism remain unclear. Nevertheless, the visual results may be quantified, and this model seems useful for studies of the natural history as well as of drug intervention.

We thank New England Nuclear for providing indium-111 chloride. This study was supported in part by a grant from the Colorado Heart Association. FWV is a research fellow of the Niels Stensen Stichting, Amsterdam, The Netherlands.

\section{References}

1 Stratton JR, Ritchie JL, Hamilton GW, Hammermeister KE, Harker LA. Left ventricular thrombi: in vivo detection by indium-111 platelet imaging and two dimensional echocardiography. Am F Cardiol 1981; 47: 874-81.
2 Ezekowitz MD, Burrow RD, Heath PW, Streitz T, Smith EO, Parker DE. Dizgnostic accuracy of indium-111 platelet scintigraphy in identifying left ventricular thrombi. Am f Cardiol 1983; 51: $1712-6$.

3 Asinger RW, Mikell FL, Elsperger J, Hodges M. Incidence of left ventricular thrombosis after acute transmural myocardial infarction. Serial evaluation by two-dimensional echocardiography. $N$ Engl f Med 1981; 305: 297-302.

4 Stratton JR, Thiele BL, Ritchie JL. The effects of antithrombotic drugs in patients with left ventricular thrombi: assessment with indium-111 platelet imaging and two-dimensional echocardiography. Circulation 1984; 69: 561-8.

5 Stratton JR, Lighty GW Jr, Pearlman AS, Ritchie JL. Detection of left ventricular thrombus by two-dimensional echocardiography: sensitivity, specificity, and causes of uncertainty. Circulation 1982; 66: 156-66.

6 Asinger RW, Mikell FL, Sharma B, Hodges M. Observations on detecting left ventricular thrombus with two dimensional echocardiography: emphasis on avoidance of false positve diagnosis. Am F Cardiol 1981; 47: 145-56.

7 Scheffel U, Tsan MF, McIntyre PA. Labeling of human platelets with [111 In]-8-hydroxyquinoline. F Nucl Med 1979; 20: 524-31.

8 Stratton JR, Ritchie JL, Hammermeister KE, Kennedy JW, Hamilton GW. Detection of left ventricular thrombi by radionuclide angiography [Abstract]. Am f Cardiol 1981; 47: 474.

9 Ezekowitz MD, Smith EO, Fahmy A, Kellerman DJ. The effect of subcutaneous heparin on the incorporation of indium-111 labelled platelets into mural left ventricular thrombi developing during the acute phase of myocardial infarction [Abstract]. $\mathcal{F} \mathrm{Nucl}$ Med 1982; 23: P47.

10 Veterans Administration Hospital Cooperative Clinical Study Group. Anticoagulants in acute myocardial infarction. $\mathcal{F A M A}$ 1973; 225: 724-9.

11 Vandenbossche JL, Cong BH, Bernard R, Englert M. Left ventricular thrombosis after myocardial infarction [Letter]. $N$ Engl $\mathcal{F}$ Med 1981; 305: 1416.

12 Friedman MJ, Carlson K, Marcus FI, Woolfenden JM. Clinical correlations in patients with acute myocardial infarction and left ventricular thrombus detected by two-dimensional echocardiography. Am 7 Med 1982; 72: 894-8.

13 Bergmann SR, Lerch RA, Mathias CJ, Sobel BE, Welch MJ. Noninvasive detection of coronary thrombi with In-111 platelets: concise communication. F Nucl Med 1983; 24: 130-5.

14 Stratton JR, Thiele BL, Ritchie JL. Platelet deposition on Dacron aortic bifurcation grafts in man: quantitation with indium-111 platelet imaging. Circulation 1982; 66: 1287-93.

15 Roelandt J, van Dorp WG, Bom N, Laird JD, Hugenholtz PG. Resolution problems in echocardiology: a source of interpretation errors. Am $\mathcal{f}$ Cardiol 1976; 37: 256-62.

16 Meltzer R, Guthaner D, Rakowski H, Popp RL, Martin RP. Diagnosis of left ventricular thrombi by two-dimensional echocardiography. Br Heart f 1979; 42: 261-5.

17 Thompson JE, Weston AS, Sigler L, Raut PS, Austin DJ, Patman RD. Arterial embolectomy after acute myocardial infarction: a study of 31 patients. Ann Surg 1970; 171: 979-86.

18 Ezekowitz MD, Wilson DA, Smith EO, Kanaly PJ, Parker DE. Indium-111 platelet scintigraphy and two dimensional echocardiography in the diagnosis of left ventricular thrombi [Abstract]. Am $\mathcal{F}$ Cardiol 1981; 47: 474.

19 Ezekowitz MD, Wilson DA, Smith EO, et al. Comparison of Indium-111 platelet scintigraphy and two-dimensional echocardiography in the diagnosis of left ventricular thrombi. $N$ Engl $f$ Med 1982; 306: 1509-13. 